\title{
THE INTERPERSONAL MEANING OF MOCKING CHANT TO FOOTBALL PLAYERS BY ENGLISH PREMIER LEAGUE SUPPORTERS
}

\author{
Nur Rochman Fatoni [1], Riyadi Santosa [2], Djatmika [3]
}

\author{
[1] nrf.fatoni@student.uns.ac.id, [2] riyadisantosa@staff.uns.ac.id, [3] djatmika@staff.uns.ac.id \\ Universitas Sebelas Maret \\ Surakarta, Central Java, Indonesia
}

\begin{abstract}
The discussion of the social relationship meaning between participants in a language interaction, mainly spoken, is fascinating. Sport, one of the discourses familiar to the social community, is still rarely uncovered in language research. This research highlights the mocking chant's interpersonal meaning to football players sung by supporters of the English Premier League (EPL), especially from the six biggest clubs (the big six). It uncovers interpersonal meaning by analyzing the MOOD system, modality, and polarity within the Systemic Functional Linguistic approach. The analysis results are obtained through domain, taxonomy, componential and cultural themes analysis. MOOD system analysis shows an equal position between supporters and listeners. The finding also supports that they exchanged information in the discourse, which tells the bad things experienced by the player and the disgrace of the mocked players. However, it must be noted that the mocked players are positioned at different points of view because of the negative value of the polarity. The modality analysis shows the confidence of supporters when singing the mocking chant to the players.
\end{abstract}

Keywords: interpersonal meaning, supporter's chant, mood, modality and polarity, systemic functional linguistics.

\section{INTRODUCTION}

The cultural and social discussion cannot be separated from the discussion of language. It is an extension of the opinion that language is one of the products of culture (Mujib, 2009). Speaking language is not just talking about communication. Speaking language also talks about human expressions that carry messages from human thoughts in which identities, values, perspectives, norms, rules, beliefs, emotions, and ideas of mind (Darmojuwono, 2016). Related to this also, the current trend of language research is plural about the relationship between social interaction and the use of language as a means of delivering messages.

The real relationship of social and language is in the use of language in certain social groups carrying a kind of identity that can be seen, for example, from interactions and relationships between speakers
(Tamtomo, 2018). From this statement, the use of language will reveal the speaker's identity and the speech partner and the interpersonal relationships between them. The use of language influences and is influenced by social interactions that surround it (Yusa et al., 2017). It is the context around language. So from this, we can see a close relationship between language, context, and interaction between people in it (Ardi et al., 2018).

As said above, language cannot be seen as something separate because language is a product of the surrounding social environment or, in this case, commonly called context. The context affects how language creates unique characters and differs between the types of context in one discourse to another. It includes how interactions that develop between participants in a discourse can be seen from the language and context of 
the situation and language (Santosa et al., 2011b). The interactions developed through social media discourse, newspapers, magazines, speeches, or songs and songs have different characteristics and are very interesting for further investigation.

In the development of language and social life, now the plural of exchanging messages between people is often conveyed through song. Messaging with song discourse has been found in various fields (Low, 2013; McKerrell, 2015; Zahoor \& Janjua, 2016). Not only in the entertainment, but the trend has spread to politics, education and even sports, particularly football. In addition to different contexts, variations in the use of songs in message exchanges are also found in various song genres (HĂNG, 2016; Nieto Alvaro, 2012) such as pop, dangdut, rock, or contemporary genres such as musicals (Plemenitaš, 2016), yells, chant, jingle products, and songs for education (Coats, 2016).

Social interaction in sports discourse, especially in football, is also exciting to talk about. In football, there is a song genre used to convey the message, namely the chant of the supporters. In this case, supporters in football match sing various popular songs called chants.

Into the chant has become a trend now for supporters (Marshall, 2014). Football spectators in the stadium intend to watch an exciting match, but people who ordain themselves as a group of supporters do a lot to support a team or make fun of the opposing team. One of the most common things to do is sing a chant.

Historically, the language phenomenon of this chant is exciting. It began when chants, in football, emerged as a form of sending messages from football supporters. The chant singing of these supporters originally came from Hooligan's creativity and fanaticism (supporters of football in England). The singing of a chant at a football game gives a new atmosphere in a positive sense. The supporters can express their enthusiasm in support or even can also express the emotions of the soul in the form of mock to football players as a form of protest. The chant can also be an identity for the supporters of the club. It has become an entertainment for connoisseurs and football fans in a match.
However, in a chant, the message expressed is not only mere support but can also be in the form of overflowing feelings, social criticism, satire, and a chant in the form of mockery. All of these messages must be related to the team or part of the team, such as players. The mocking chants to the players are amusing to note that the use of language in the sports, especially in football matches, reflects the interpersonal relationships between participants in it. It can be an exciting area to study where chants' use is influenced by the context that appears in a match to the meaning of interaction that arises from interactions in the use of language used by supporters to sing the chant.

Halliday explained that the use of language includes interactions where participants in a discourse exchange messages and meanings. The use of certain grammatical and diction systems carry varied and unique meanings and messages (Fatoni, 2018). Messages exchanged in an interaction are generally in the form of goods, services, or information. Djatmika (2012) also mentioned that the message exchange event was divided into asking or giving. Then the exchange that occurs in a discourse can take the form of asking for goods/services or information and giving goods/services or information. The relationship formed in the language interaction can be examined in the interpersonal metafunction/meaning of language in a discourse, in this case the supporters' chants which contain mockery to players. The relationship and interaction in the supporters' chant discourse is investigated by the interpersonal metafunction of the Systemic Functional Linguistic approach because, in the metafunction, the meaning is created by the realization of grammatical elements that treat language as an experience (Halliday \& Hasan, 1992). This is in line with Khaofia (2018) who said that, in its use by speakers, language has three communicative functions, namely describing, exchanging, and organizing experiences.

The analysis of words, clauses, and grammatical systems in a discourse using Functional Systemic Linguistics has been carried out, such as research from Hidayat (2018) that uses this approach. However, it only focuses on the transitivity, while Djatmika et al. (2011) use SFL in language 
analysis in education. Discourse studies using the SFL approach are also commonly found in research on written discourse or reading material such as research by Izzati (2019) that examines grammatical intricacy in children's short stories. Research on the interpersonal meaning of discourse has been conducted several times by other researchers. Qani'ah (2016) attempted to explore social relationships that are built in an editorial text in Jakarta. While Mafruchatunnisa \& Agustin (2016) investigated the interpersonal meaning of Michele Obama's speech. Interpersonal meaning research is indeed often found in data from oral discourse such as in research belonging to Mustikawati \& Sumarlam (2017), which explores interpersonal meaning in conversations or dialogs in the Mata Najwa Talkshow. Research on mock in language interactions researches much on mock or mockery in personal interactions and with pragmatic approaches (Haugh, 2014).

The SFL approach has also been used to analyze languages from unusual domains, such as in the religious domain (Ingold, 2014). The Halliday's SFL has also been widely used in mass media discourse research and focuses on the structure and conjunction of texts (Arifah et al., 2019). As also stated above, language research in rhythmic literary works such as songs and poetry is indeed impressive. Kusumaningsih et al. (2019) explore the song's pedagogical meaning to uncover vulgar language in dangdut songs. Jamdar et al. (2015) revealed the meaning of songs and emotions created from song lyrics based on the audio features produced. Besides, Rahman (2018) examines perceptions of the song 'Sacred in Dust' and also Roshanfekr et al. (2017), who focus on children's poetry.

More in-depth analysis of language and participant relations needs to be examined more because language is not only about structure but also about its use and its relation to the context. From some of the previous studies above, researchers found exciting research gaps to study. Analysis of the meaning of the chants in football is still rarely examined. Another novelty of the present study is exploring the interpersonal meaning created in the supporters' chant lyrics by using the Systemic Functional Linguistic approach (henceforth SFL). The supporters' chant at a soccer game contains unique language and is influenced by the context surrounding it.

The relationship between participants in a discourse can be investigated from various approaches, including the SFL approach. Emilia (2014) and Wengrum (2015) emphasized that the SFL constructs the meaning in the social interaction by linking the semantics of discourse with the context and culture. Therefore this research focuses on exploring the interpersonal meaning of mock chants in English league supporters or English Premier League with SFL. This study will see how supporters place attitudes, opinions, and positions on other participants in the discourse. This research is included in discourse analysis using the Functional Systemic Linguistics approach.

The interpersonal meaning in language use is the language user's action in social interaction (Santosa, 2003). In this interaction, the interpersonal meaning is reflected in the language transaction and also the exchange of information (Wiratno, 2018). In the context of speakers, interpersonal meaning represents speakers' potential as participants (involved) in language communication. The interpersonal meaning may disclose how the relationship is built between the speaker and the speech partner or writer and reader in a discourse. At the clause level, the interpersonal meaning can be identified from the system and function of the lexicogrammar that is built and involves the participants.

Halliday \& Matthiessen (2014) illustrate that there is always a relationship between two people who interact with each other in language interactions. The relationship between these two people will create two fundamental types of interaction functions, namely giving and asking. In the interaction function, which is always exchanged are goods or services and information. Clauses that contain giving or asking for information are called propositions. While the clause provides goods or services and requests for goods or services is called a proposal.

Furthermore, this interpersonal function is realized by the MOOD system, which explains the real actions that exist in language interaction. In general, the MOOD system is divided into indicative (declarative, 
interrogative) and imperative. In the grammatical structure of English, the indicative clause: declarative has a Subject $(\mathrm{S})$ that precedes Finite $(\mathrm{F})$. In the indicative clause: interrogative, Finite $(\mathrm{F})$ will precede the subject. In the imperative clause, there is no subject or finite, but it has a predicate.

According to Gerot \& Wignel (1995), interpersonal meaning in a discourse is about how participants, in this case, speakers' attitudes and judgment. Meanwhile, according to Halliday \& Matthiessen (2014) and Djatmika (2012), the determination of attitudes and comments from speakers can be seen from the use of modality and polarity. In addition to MOOD, interpersonal meaning can also be seen from its polarity and modality. Polarity is about 'yes' and 'no' talk. Polarity in English is seen in the use of finitewith/without negator 'not,' for example, 'do' and 'do not.' Favorable and unfavorable assessments, according to (Djatmika, 2012) will be seen if juxtaposed with the attitude lexis/emotive word. In brief, modality focuses on the speaker's statement of attitude or commentary about the possibilities and necessities. The discussion of modality provides another alternative meaning between the negative and positive angles of polarity (Wiratno, 2018). The modality system is divided into modulation and modalization. (Santosa, 2003) explained that modulation expresses the meaning of the proposal (goods/services) and is further divided into the obligatory meaning (necessity) and the meaning of inclination (desires). Meanwhile, the modality explains the meaning of propositions (information), which is divided into probability and usuality. Modality contains three levels of expression: high, medium, and low (Eggins, 2004; Gerot \& Wignel, 1995).

Table 1. Type, level, and samples of modality

\begin{tabular}{|c|c|c|c|}
\hline \multirow{2}{*}{ Modality } & \multicolumn{3}{|c|}{ Modality levels } \\
\hline & High & Medium & Low \\
\hline Probability & $\begin{array}{c}\text { Must, } \\
\text { cannot, } \\
\text { sure }\end{array}$ & $\begin{array}{c}\text { Probably, } \\
\text { will be, } \\
\text { should }\end{array}$ & $\begin{array}{l}\text { Maybe, } \\
\text { perhaps }\end{array}$ \\
\hline Usuality & Always & $\begin{array}{l}\text { Usually, } \\
\text { often }\end{array}$ & $\begin{array}{l}\text { Sometimes, } \\
\text { never, once }\end{array}$ \\
\hline Obligation & $\begin{array}{l}\text { Must, } \\
\text { have to, }\end{array}$ & $\begin{array}{l}\text { Should, } \\
\text { will, } \\
\text { suppose }\end{array}$ & $\begin{array}{c}\text { May, can, } \\
\text { might }\end{array}$ \\
\hline Inclination & Need to, & Want to, & Willing, can \\
\hline
\end{tabular}

\begin{tabular}{cr}
\hline determine $\begin{array}{r}\text { keen, } \\
\text { won't }\end{array}$ \\
\hline Source: (Halliday \& Matthiessen, 2014)
\end{tabular}

Source: (Halliday \& Matthiessen, 2014)

\section{METHOD}

This research is a descriptive qualitative type. That means the data and analysis results can be presented in the form of words rather than numbers (Heigham \& Croker, 2009). Besides, as mentioned in the introduction above, this study uses the Functional Systemic Linguistics approach proposed by Halliday \& Matthiessen (2014) to analyze data. This approach is used to probe the interpersonal meaning of the supporters' mocking chant of the EPL players by looking at the MOOD system, polarity, and modality.

The data sources are documents in the form of English Premier League (henceforth EPL) supporters' chant lyrics available at fanchant.com. The selected chants for this study are the chants of the big six's supporters. The authors focus on mocking chants aimed at players. The authors analyzed how interpersonal relationships and interactions in the chant are sung by supporters to mock the player.

The data in this study were obtained through content analysis techniques (Stemler, 2015). According to Gottschalk (2013), content analysis in spoken language functions to filter out what is spoken by the speaker and the message conveyed from the speech to separate data and not data from the data sources mentioned earlier. From the source, data of the supporters' chant lyric document that was sung at the stadium when the EPL club plays, the analysis of the content produced data in the form of words and clauses. Furthermore, the filtered and collected data will proceed to the MOOD, modality, and polarity analysis before coming to a more simultaneous analysis stage.

The data were then analyzed using analytical techniques (Spradley, 1980) in the form of domain analysis, taxonomic analysis, component analysis, and cultural theme analysis. In this article, the authors will describe the Spradley's (1980) method analysis technique in analyzing the interpersonal meaning with the SFL approach. 


\section{RESULTS AND DISCUSSION Research result}

Based on the focus of the research mentioned earlier, then from the data domain, the mocking chant is separated again in the big six that have been selected. The purpose of data classification in the domain is in line with the function to separate data from non-data (Santosa, 2017). There will be one mocking chant data from each of the six clubs. The domain containing the mock chant from each club will later in the compounding analysis be on the X-axis, which is to the left of the table.

The second analysis tool is taxonomic analysis or the use of categories from the theory/approach used, Systemic Functional Linguistic, to reduce and organize data on language phenomena that occur (Santosa, 2017). Data in the form of mocking chants from 6 clubs were classified and analyzed with the MOOD system, modality, and polarity, which are part of the interpersonal metafunction (Halliday \& Matthiessen, 2014). The MOOD classification system that contains clause types (declarative, interrogative, and imperative) as well as clause functions (propositions and proposals), the modality and polarity system will reveal how the status or position as well as the attitudes and comments of the chant speaker to the speech partners and other participants. In the componential table, the categories in the taxonomy are on the Y-axis at the top of the table.

The two analytical tools above are combined into an analysis or table called componential. The X-axis or data domain and the Y-axis or category taxonomy will intersect.

Santosa (2017) said that in the componential analysis, the relationship among categories in the domain and the previous taxonomy are built to show the relationship patterns, interaction patterns, and behavior patterns from the meeting of the two axes. Componential tables can be seen in Tables 02 and 03.

Finally, the data analysis method (Spradley, 1980) arrives at the analysis of cultural themes, which will be explained in detail in the following section. According to Santosa (2017), the purpose of analyzing cultural themes is to interpret the pattern of relationships between the categories mentioned earlier into the context of the situation and cultural context that surrounds the mock chant.

From the data below, we found the number of clauses from the mocking chant of the 6 EPL clubs called 'the big six,' which is totaling 52 clauses. The distribution of mocking chant clauses in the analysis of interaction functions and MOOD types can be seen in the following table:

Table 02: Componential realization of the MOOD System on the 'Mocking' chants of players

\begin{tabular}{|c|c|c|c|c|c|c|}
\hline \multirow[b]{2}{*}{ Club } & \multicolumn{2}{|c|}{ Interaction Function } & \multicolumn{3}{|c|}{ MOOD Type } & \multirow[b]{2}{*}{$\begin{array}{l}\text { Minor } \\
\text { clause }\end{array}$} \\
\hline & $\begin{array}{l}\text { Propositi } \\
\text { on }\end{array}$ & Proposal & $\begin{array}{c}\text { Declarativ } \\
\mathrm{e}\end{array}$ & $\begin{array}{c}\text { Imperati } \\
\text { ve }\end{array}$ & $\begin{array}{l}\text { Interrogati } \\
\text { ve }\end{array}$ & \\
\hline M. City & 5 & 0 & 3 & 0 & 2 & 0 \\
\hline Liverpool & 9 & 0 & 3 & 0 & 6 & 0 \\
\hline Chelsea & 4 & 0 & 4 & 0 & 0 & 0 \\
\hline Tottenham & 3 & 0 & 1 & 0 & 2 & 2 \\
\hline Man. United & 7 & 0 & 7 & 0 & 0 & 5 \\
\hline Arsenal & 14 & 0 & 14 & 0 & 0 & 3 \\
\hline $\begin{array}{l}\text { Number of } \\
\text { Clauses }\end{array}$ & 42 & 0 & 32 & 0 & 10 & 10 \\
\hline Percentage & $81 \%$ & $0 \%$ & $62 \%$ & $0 \%$ & $19 \%$ & $19 \%$ \\
\hline
\end{tabular}

Table 02, which contains the MOOD System analysis above, has 42 major clauses in the form of propositions out of a total of 52 clauses. In the mocking chant to this player, there are two MOOD types, namely declarative and interrogative type clauses. There are 32 indicative: declarative clauses and ten indicative: interrogative clauses. In addition to the major clauses mentioned above, we also found ten minor clauses. Here is an example of a minor clause at the clubs' Chant of Tottenham, Arsenal and Manchester United:

Heeeeeey hey Campbell: minor clause

Wanker...: minor clause

Torres...: minor clause

Oh.. Robbin...: minor clause 
The examples above show that the minor clause in the mocking chant on these players takes the form of exclamations or nicknames.

Furthermore, the number of major clauses is more significant than minor clauses. Then, it was analyzed by the MOOD system, its modality, and its polarity. In the major clause, the proposals and imperative clauses were not found. As explained above, in addition to the declarative form that dominates 32 clauses, the lexicogrammatical structure of the mocking chant clauses also shows two kinds of interrogative clause structures. There are four interrogative clauses, and six yes/no interrogative clauses. Uniquely, the six yes/no interrogative clauses were only found from one chant, namely from the Liverpool club. The following is an example of a MOOD System analysis on the clause of the Manchester United club:

1.

\begin{tabular}{|l|l|l|}
\hline He & wears & a frock \\
\hline S & F / P & C \\
\hline Mood & \multicolumn{2}{|c|}{ Residue } \\
\hline
\end{tabular}

2.

Indicative: declarative; proposition

\begin{tabular}{|l|l|l|}
\hline he & loves & the cock \\
\hline S & F / P & C \\
\hline Mood & Residue \\
\hline
\end{tabular}

Indicative: declarative; proposition

Following is an example of an analysis of the MOOD System in the clause of the Arsenal club:

3.

\begin{tabular}{|c|c|c|c|}
\hline Oh Robin & she & said & no \\
\hline Vocative & S & $\mathrm{F} / \mathrm{P}$ & $\mathrm{C}$ \\
\hline Re- & Mood & & \\
\hline
\end{tabular}

4.

\begin{tabular}{|c|l|l|}
\hline You & 're & a cunt Robin \\
\hline S & F & C \\
\hline \multicolumn{2}{|c|}{ Mood } & Residue \\
\hline
\end{tabular}

Indicative : declarative ; proposition

The following is an example of the MOOD System analysis in the clause of the Arsenal club:

5.

\begin{tabular}{|l|l|l|l|}
\hline Why & is & it & so? \\
\hline Wh / c & F & S & C \\
\hline Re- & \multicolumn{4}{|c|}{ Mood } & -sidue \\
\hline
\end{tabular}

Indicative: wh-question; proposition

6.

\begin{tabular}{|l|l|l|}
\hline I & wanna & know \\
\hline S & F & P \\
\hline \multicolumn{2}{|c|}{ Mood } & Residue \\
\hline
\end{tabular}

Indicative: declarative; proposition

The following is an example of the MOOD System analysis in the clause of the Chelsea club:

7.

\begin{tabular}{|l|c|l|}
\hline $\mathrm{He}$ & cheats & on the right \\
\hline $\mathrm{S}$ & $\mathrm{F} / \mathrm{P}$ & $\mathrm{C}$ \\
\hline \multicolumn{2}{|c|}{ Mood } & Residue \\
\hline
\end{tabular}

Indicative: declarative; proposition

8.

\begin{tabular}{|l|l|l|}
\hline $\mathrm{He}$ & is & a bag of shire... \\
\hline $\mathrm{S}$ & $\mathrm{F}$ & $\mathrm{C}$ \\
\hline \multicolumn{2}{|c|}{ Mood } & Residue \\
\hline
\end{tabular}

Indicative : declarative ; proposition

The following is an example of the MOOD System analysis in the clause of the Liverpool club:

9.

\begin{tabular}{|l|l|l|l|l|}
\hline Have & you & ever & seen & $\begin{array}{l}\text { Lampard } \\
\text { [win the } \\
\text { Euro] }\end{array}$ \\
\hline F & S & Adj. & P & C \\
\hline \multicolumn{2}{|c|}{ Mood } & \multicolumn{3}{|c|}{ Residue } \\
\hline
\end{tabular}
10.

Indicative : interogatif; proposition

\begin{tabular}{|c|c|c|}
\hline Lampard & Win & the Euro \\
\hline S & F / P & C \\
\hline \multicolumn{2}{|c|}{ Mood } & Residue \\
\hline
\end{tabular}

Indicative : declarative ; proposition

The following is an example of the MOOD System analysis in the clause of the Manchester City club:

11. proposition

\begin{tabular}{|l|l|l|l|}
\hline Who & 's & $\begin{array}{l}\text { [That] } \\
\text { running } \\
\text { down }\end{array}$ & the wing \\
\hline Wh / S F & P & C \\
\hline Re- & Mood & -sidue & \\
\hline
\end{tabular}

12.

\begin{tabular}{|l|l|l|l|}
\hline Well & It & 's & $\begin{array}{l}\text { Giggs and } \\
\text { Imogen }\end{array}$ \\
\hline continuative & S & F & C \\
\hline Re- & Mood & -sidue \\
\hline
\end{tabular}


Indicative : declarative ; proposition

The next is an example of the Whinterrogative clause in the Manchester City club and yes/no interrogative in the Liverpool club using the MOOD system analysis of its interaction function and MOOD type.

13. Wh- question

\begin{tabular}{|l|l|l|l|}
\hline Who & 's & $\begin{array}{l}\text { [that } \\
\text { shagging }\end{array}$ & $\begin{array}{l}\text { round } \\
\text { Cardiff }\end{array}$ \\
\hline Wh / S & F & P & Adj. \\
\hline Re- & Mood & \multicolumn{2}{|c|}{-sidue } \\
\hline
\end{tabular}

proposition

Indicative: wh- interrogative;

14. Yes/no question

\begin{tabular}{|l|l|l|l|l|}
\hline Have & you & ever & seen & $\begin{array}{l}\text { Lampard } \\
\text { [win the } \\
\text { Euro] }\end{array}$ \\
\hline F & S & Adj. & P & C \\
\hline \multicolumn{2}{|c|}{ Mood } & \multicolumn{3}{c|}{ Residue } \\
\hline
\end{tabular}

Indicative : interogatif; proposition

The mood structure of this mocking chant varies. In addition to the use of 14 clauses with You pronouns and 16 clauses with he/she pronouns, there are subjects with 'wh-question,' 'it,' 'I,' mentioning names and nicknames for example 'the wife.' There are also three vocatives and one continuative. In this mocking chant, there is a conjunction that starts the clause.

15.

\begin{tabular}{|l|l|l|}
\hline $\mathrm{He}$ & 's & half a boy \\
\hline S & F & C \\
\hline \multicolumn{2}{|c|}{ Mood } & Residue \\
\hline
\end{tabular}

Indicative : declarative ; proposition
16.

\begin{tabular}{|c|c|c|}
\hline She & Said & No \\
\hline S & F / P & C \\
\hline Mood & \multicolumn{2}{|c|}{ Residue } \\
\hline
\end{tabular}

Indicative: declarative; proposition

Halliday \& Matthiessen (2014) and Gerot \& Wignel (1995) emphasized that polarity and modality related to the use of finite in clauses. The polarity value is marked by the existence of finite, which means 'yes' and 'no' (proposition) or 'do' and 'do not' paired with attitude lexis. The meaning of polarity becomes negative if there is a negative polarity or lexis. There is no negative polarity in the grammatical structure of mocking chant. Many predicates of lexis are dominated by negative lexis. Then the results found 29 clauses with negative polarity values and fewer positive polarity values, 23 clauses. It happens when positive polarity incorporated with attitude lexis that conveys negative tone to other participants. This language phenomenon can be found, for example, in clauses 13 and 15 above. In this clause, the positive polarity finite 'is' combined with negative lexis such as 'shagging' and 'half a boy.'

Meanwhile, the modalities supporters' mocking chants to the players of 'the big six' tend to be very limited in number. In the mocking chant of EPL players, only five modalities were found in the form of low usuality modalities with the word mark 'ever' and one inclinative modality with a 'wanna' marker. See the modality and polarity analysis in the following table.

Table 03. Componential realization of the MOOD System on the 'Mocking' chants of players

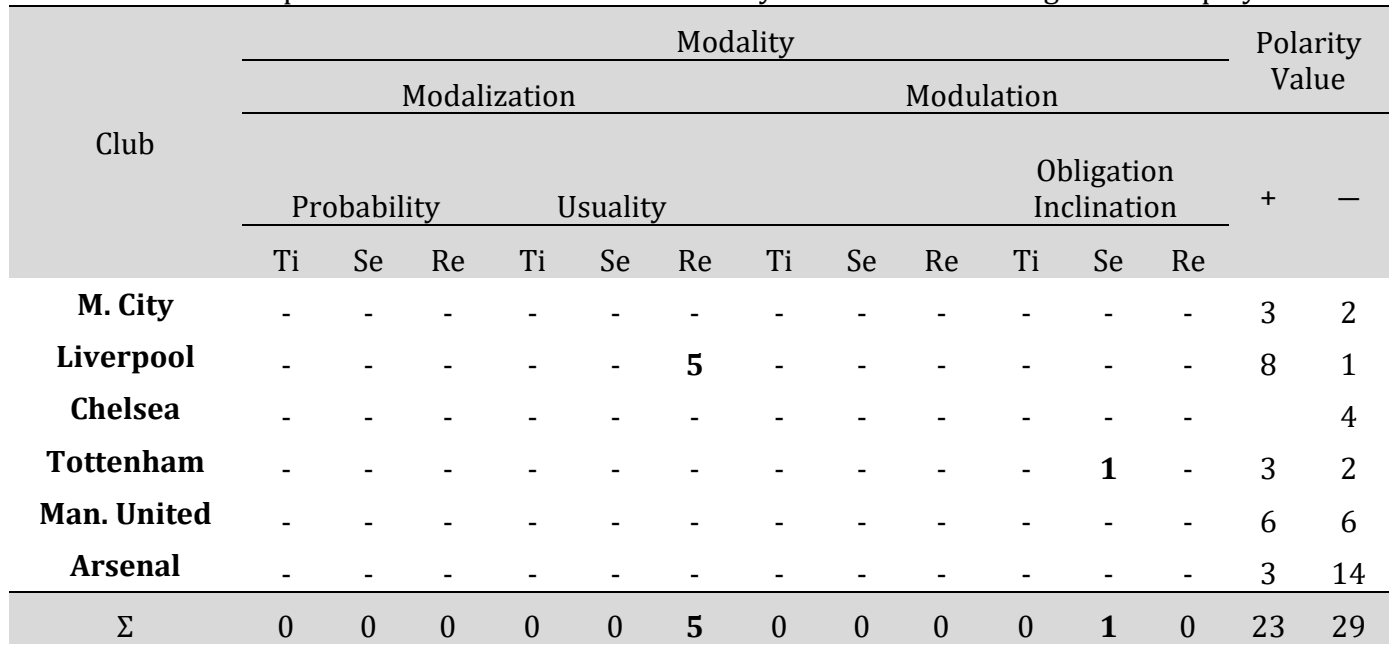




\section{Discussion}

In this interpretation stage, the researcher analyzed the cultural themes. The findings of the 'mocking' Chant Componential Analysis to players in English Premier League clubs are juxtaposed in the context and the categories of the applicable approaches (Santosa, 2017). In the componential table above, the dominant clause with the interaction function proposition and the propositional clause are not found. In mocking chants, $81 \%$ of proposition clauses and the remaining $19 \%$ are minor clauses.

The dominance of the proposition clause conveys the interpersonal meaning that in the interaction that occurs when the supporters sing the chant, they are exchanging information. It is related to the function of the proposition clause is to request or provide information (Santosa, 2003). Regarding the context, the information exchanged is about the players they mock or support. The information is related to disgrace, achievement, prejudice, or about the gossip circulating about the player. However, this information is used as material for supporters to mock these players.

Meanwhile, exclamations or nicknames dominate minor clauses. Many screams contain nicknames for the players they mocking. The function of this nickname is to intensify the mockery for the player. In addition to the exclamation, minor clauses take the form of calls or nicknames. These calls serve to clarify to whom the mocking chant is addressed.

In the propositional clauses, $62 \%$ of indicative propositions are declarative. This figure seems to imply information delivery to other participants. Even though the information exchanged means that it is a judgment or opinion that seems to be a fact. Contextually, supporters' opinions are mockery or bullying to the addressed players. As explained earlier, these opinions and jokes are presented using disgrace or mere supporters' opinions. It serves to bring down the opponent's players who are mocked or disrupt the opponents' concentration when competing with the team they support.

The facts in the MOOD system clause above indicate the participants' status or position in interactions, namely to exchange messages (Djatmika, 2012; Gerot \& Wignel,
1995; Halliday \& Matthiessen, 2014; Santosa, 2003). The chant is supporters' expression in supporting or mocking their opponent team, especially the mocked players. The chant involves three participants: supporters who sing chants as speakers, speech partners that can consist of anyone who listens to this chant such as supporters or other spectators, and the mocked players as participants in the discourse. There were different statuses in the interactions of the three participants. The dominance of the propositional clause implies that supporters are at the same level as their speech partner. The percentage of declarative clauses also means that they have an equal position with the mocked players. In terms of lexicography, the absence of a propositional clause implies that none of the participants who dominate or otherwise become inferior because what is exchanged in the mocking chant is only information, not providing or asking for goods and services. The proposition clauses that contain the information in this chant mean the statements that make fun of the players.

However, the interpretation is different from the existence of an interrogative clause in this mocking chant. In the frame of proposition and declarative clauses, the type of interrogative clause generally functions to ask the speech partner for information from the speaker. In this mockery, the interrogative clause does not function purely asking for information. The mocking clause does not function as a question, which is a proposition that asks for information. However, the interrogative clause here functions to involve the speech partner in the interaction when singing the chant. From what is asked, we can see common knowledge or information that has been known between the speaker and the speech partner. Another function of the highlighted interrogatives is alluding and exposing the disgrace of the mocked player. From this fact, it can be interpreted that the structure of indicative clause: interrogative: the proposition still positions supporters equally to the speech partners in the form of other people who listen to this chant. Nevertheless, the interrogative clause takes the form of rhetorical questions that do not require answers because the information in question is in the clause, and it is intended to expose the disgrace of the mocked player. It 
makes the position of participants (the mocked players) unequal by the supporters.

In the MOOD structure, the subject is an aspect that becomes the source of negotiation. Generally, the dominant use of mood structures that position the subject at the beginning of the clause illustrates that the chant writer still places himself as a party that is relatively balanced or equal to the reader. The clause used to place the player as a subject means that the player is not the party that must do something like the propositional clause or imperative form that starts the clause with a predicate.

The interpersonal meaning can also be seen from the modality system in the discourse constituent clauses. The actual modality can also be used as a mark of judgment from the speaker, which is between the meaning of 'yes' and 'no' (Halliday \& Matthiessen, 2014; Djatmika, 2012; Santosa, 2003). The modality shows the attitudes and the speakers' opinions about how strong the argument of something is conveyed. From the findings presented above, not all modalities are used in the mocking chant clauses of players. There are only modalities of low-level usuality and modulation of medium-level inclination. The lack of use of various modalities (usuality and probability) means that supporters affirm the mockery with confidence and state the information in the mockery is a truth. The 'ever' capitalization of low usuality in the Liverpool chant that insults Lampard (e.g., 14) is not asking about his habits because when the chant was sung, everyone knew that Lampard had never won a European championship title. Besides, the modulation of inclination of 'wanna' level does not mean a desire to get information or even goods and services, but it is indeed to allude the mocked players.

According to Djatmika (2012), polarity and lexis can be used to see the speakers' views based on the attitudes lexis and the polarity used in a clause. In general, positive polarity shows a positive connotation (Volkova, 2012). Polarity has a formula law that polarity $(-)$ meets lexis attitude $(-)$ will be positive; polarity $(+)$ meets lexis attitude $(-)$ will be negative, polarity $(+)$ meets lexis attitude $(+)$ will be positive, whereas polarity $(-)$ meets lexis attitude $(+)$ will be negative. In the above findings, there are not many negative polarities found, such as 'do not' or 'not,' but 29 negative polarities dominate the polarity. It is because the supporters use many lexemes that have negative connotations to the mocked players.

Analyzing the meaning of language is indeed very interesting. Because the meaning of language cannot be separated from the social context and interactions that carry the language (Rahardjo, 2010), research on the interpersonal meaning between participants in social interaction like this is essential to add discourse analysis studies (applied discourse analysis) and applied linguistics ). In the use of a systemic functional linguistic approach as a linguistic analysis approach, language meaning research tends to massively uncover the meaning of language for written discourse, for example in Sukriyah et al. (2018) and language in mass media (Yuliana \& Imperiani, 2017), while in oral discourse much research has focused on the oral discourse on conversation (Santosa et al., 2011a) or other types of speeches or talk shows as in Mafruchatunnisa \& Agustin (2016). This study also offers another insight into the analysis of oral discourse in football and in the genre of contemporary songs (chants), which are still rarely discussed. Besides, this research not only presents the description of linguistic categories in a language but also followed by juxtaposing with the context to see the interpersonal meaning of the language of interaction.

\section{CONCLUSION}

The supporters' chants in the EPL, especially at the Big Six clubs, display several types of the meaning of discourse, one of which is mocking chants. It certainly shows that the interaction between participants in the mocking chant discourse, namely supporters who sing chants, the mocked players, and listeners. Through the MOOD system, modality, and polarity with the SFL approach, social relations can be explored in terms of the interpersonal meaning between participants in the supporters' mocking chants. The classification of MOOD system that contains clause types (declarative, interrogative, and imperative) as well as clause functions (propositions and proposals), the modality, and polarity system reveals how the status as well as the attitudes and 
comments of the chanters to the speech partners and other participants.

The findings of the analysis and discussion on MOOD type, interaction function, mood structure, modality, and polarity lead to the study's conclusion. From the lexicogrammar view, each of the mocking chant clauses seen from the MOOD system analysis, the supporters who sing the chant place themselves in an equal and balanced position with the speech partner or listener. There is a special note in this mocking chant MOOD where supporters position the mocked players at different angles, even though they are still equal. From the modality analysis, supporters have confidence in expressing mock to players with mock, which is a disgrace from the mocked players in the chant. Polarity breaks down the views between participants. As evidenced by the negative polarity values derived from the negative attitude lexis found in the mocking chant, supporters who act as speakers have a negative view of the mocked players. The supporters positioned themselves relatively equal to the participants from the listener's side because what was exchanged was information, either something that had happened or a player's disgrace.

Eventually, the authors recommend that there are many aspects of chant discourse to be investigated besides the mocking chant, of course, with the SFL approach. The lexicogrammatical element of the text provides the object of research into grammatical and lexical structures. In this case, there is lexis that has its character, generally rough and excessive. It would be interesting for other researchers to explore other future research approaches to make it more diverse.

\section{REFERENCES}

Ardi, H., Nababan, M. R., Djatmika, \& Santosa, R. (2018). Characters ' Politeness Strategies in Giving Command: Should Translators Keep Them? 3L: The Southeast Asian Journal of English Language Studies, 24(2), 181-193. https://doi.org/http://doi.org/10.17576/3L-2018-240214

Arifah, N., Djatmika, D., \& Santosa, R. (2019). The Texture of Macro and Micro Genre on Advertisement in C'nS Magazine. Advances in Social Science, Education and Humanities Research (ASSEHR) on Third International Conference of Arts, Language and Culture (ICALC 2018), 279(Icalc 2018), 281-286. https://doi.org/10.2991/icalc-18.2019.41

Coats, G. (2016). Analyzing Song Lyrics as an Authentic Language Learning Opportunity. In A. J. Moeller (Ed.), Fostering Connections, Empowering Communities, Celebrating the World (pp. 122). Robert M. Terry.

Darmojuwono, S. (2016). Language , Culture , and Social Cognition. Wacana, Vol. 17(No. 1), 121133. https://doi.org/10.17510/wacana.v17i1.430

Djatmika. (2012). Perilaku Bahasa Indonesia di dalam Teks Kontrak dari Kacamata Linguistik Sistemik Fungsional. UNS Press.

Djatmika, Primasita, F. A., \& Priyanto, A. D. (2011). Strategi Meningkatkan Kualitas Olah Bahasa Untuk Cerita Pendek Siswa Sekolah Dasar Dengan Pendekatan Genre-Based. LiNGUA: Jurnal $\begin{array}{lllll}\text { Ilmu Bahasa Dan } & \text { Sastra, } & \text { 6(2), }\end{array}$ https://doi.org/http://dx.doi.org/10.18860/ling.v6i2.1452

Eggins, S. (2004). An introduction to Systemic Functional Linguistics. In London (Second Edi). Continuum.

Emilia, E. (2014). Introducing Functional Grammar. Pustaka Jaya. 
Fatoni, N. R. (2018). Kekhasan Diksi Valentino Simanjuntak Pada Piala Presiden 2017. Adabiyyat: Jurnal Bahasa Dan Sastra, II(1), 139-163. https://doi.org/doi:http://dx.doi.org/10.14421/ajbs.2017.01205.

Gerot, L., \& Wignel, P. (1995). Making Sense of Functional Grammar (2nd ed.). Gerd Stabler.

Gottschalk, L. A. (2013). Content Analysis of Verbal Behavior. Routledge.

Halliday, M. A. K., \& Hasan, R. (1992). Bahasa, Konteks, dan Teks: Aspek-aspek Bahasa dalam Pandangan Semiotik Sosial (A. B. Tou (ed.)). Gadjah Mada University Press.

Halliday, M. A. K., \& Matthiessen, C. (2014). Halliday's Introduction to Functional Grammar (Fourth Edi). Routledge. https://doi.org/10.1023/A:1021717531970

HẰNG, T. T. T. (2016). Mother Image In English And Vietnamese Songs - A Literary Analysis Using Transitivity System In Systemic Functional Linguistics Perspective. Vietnam National University.

Haugh, M. (2014). Jocular Mockery as Interactional Practice in Everyday Anglo-Australian Conversation. Australian Journal of Linguistics, 34(1), 76-99. https://doi.org/10.1080/07268602.2014.875456

Heigham, J., \& Croker, R. A. (2009). Qualitative Research in Applied Linguistics: A Practical Introduction (1st ed.). Palgrave Macmillan.

Hidayat, T. N. (2018). Translation Shift of A Transitivity System in Obama and Trump's Inauguration Speech. LiNGUA: Jurnal Ilmu Bahasa Dan Sastra, 13(2), 91-100. https://doi.org/10.18860/ling.v13i2.4990

Ingold, R. (2014). God, the Devil and You: A Systemic Functional Linguistic Analysis of the Language of Hillsong. Literature \& Aesthetics, 24(1), 75-86.

Izzati, N. (2019). Grammatical Intricacy dalam Cerita Pendek Karya Penulis Anak Indonesia. LiNGUA: Jurnal Ilmu Bahasa Dan Sastra, 14(1), 213-222. https://doi.org/10.18860/ling.v14i1.6710

Jamdar, A., Abraham, J., Khanna, K., \& Dubey, R. (2015). Emotion Analysis Of Songs Based On Lyrical And Audio Features. International Journal of Artificial Intelligence \& Applications (IJAIA), 6(3), 35-50. https://doi.org/10.5121/ijaia.2015.6304

Khaofia, S. (2018). Modalitas Sebagai Realisasi Makna Interpersonal Pada Talkshow Mata Najwa on Stage "Semua Karena Ahok." PRASASTI: Journal of Linguistics, 3(2), 223. https://doi.org/10.20961/prasasti.v3i2.12490

Kusumaningsih, D., Djatmika, Santosa, R., \& Subroto, D. E. (2019). Pedagogical Values in Indonesian Lyrics of Dangdut Songs: Evidences of Language Vulgarism and Gender Exploitation. Journal of Social Studies Education Research, 10(3), 311-331. https://jsser.org/index.php/jsser/article/view/1085

Low, P. (2013). When Songs Cross Language Borders. The Translator, 19(2), 229-244. https://doi.org/10.1080/13556509.2013.10799543

Mafruchatunnisa, I., \& Agustin, H. I. R. (2016). Journal of English Language Teaching Interpersonal Meanings in Michelle Obama 's Speech at Memorial Service For Dr . Maya Angelou. Journal of English Language Teaching, 5(1), 1-8. 
Marshall, T. (2014). tim marshal 2014 Where do football chants come from_ - Telegraph. The Telegraph.Co.Uk. football-chants-come-from.html

McKerrell, S. (2015). Social Distance and the Multimodal Construction of the Other in Sectarian Song. Social Semiotics, 25(5), 614-632. https://doi.org/10.1080/10350330.2015.1046216

Mujib, A. (2009). Hubungan Bahasa Dan Kebudayaan (Perspektif Sosiolinguistik). Adabiyyat, Vol 8 (No 1), 141-154.

Mustikawati, D. A., \& Sumarlam. (2017). Interpersonal Metafunction in Interactive Dialogue Mata Najwa Metro TV. LiNGUA: Jurnal Ilmu Bahasa Dan Sastra, 12(1), 11. https://doi.org/10.18860/ling.v12i1.3917

Nieto Álvaro, R. (2012). The Linguistic Path of "Romance": A Systemic-Functional Analysis and Gender Comparison of Songs of the 1950s and the 2000s. Investigaciones Feministas, 3, 7-22.

Plemenitaš, K. (2016). Songs as Elements in the Generic Structure of Film Musicals. ELOPE: English Language Overseas Perspectives and Enquiries, 13(1), 31-38. https://doi.org/10.4312/elope.13.1.31-38

Qani'ah, B. (2016). Implementasi Leksikogramatika Terhadap Hubungan Sosial Antar Pelibat Wacana Dalam Teks Editorial Teks: The Jakarta Post. Diglossia, 8(1), 32-44. https://doi.org/https://doi.org/10.26594/diglossia.v8i1.670

Rahardjo, M. (2010). Mengungkap Tabir di Balik Makna (Issue February).

Rahman, F. (2018). Persepsi Sufistik Lirik Lagu 'Suci Dalam Debu' Melalui Analisis Strata Norma. LiNGUA: Jurnal Ilmu Bahasa Dan Sastra, 13(1), 35-45. https://doi.org/10.18860/ling.v13i1.4756

Roshanfekr, A., Askari, S., \& Akbarpour, S. (2017). Types of Children Poem in Divan Al-Atfal By Sulaiman Al-Isa. LiNGUA: Jurnal Ilmu Bahasa Dan Sastra, 12(1), 1. https://doi.org/10.18860/ling.v12i1.4270

Santosa, R. (2003). Semiotika Sosial: Pandangan terhadap Bahasa (1st ed.). Pustaka Eureka.

Santosa, R. (2017). Metode Penelitian Kualitatif Kebahasaan (D. D. Purnanto, M.Hum (ed.); 1st ed.). UNS Press.

Santosa, R., Priyanto, A. D., \& Nuraeni, A. (2011a). Bahasa Demokratis Di Dalam Media Televisi Indonesia. LiNGUA: Jurnal Ilmu Bahasa Dan Sastra, 6(3).

Santosa, R., Priyanto, A. D., \& Nuraeni, A. (2011b). Genre and Register of Antagonist 's Language in Media: An Appraisal Study of Indonesian Newspapers. K@ta, 2639, 23-37. https://doi.org/10.9744/kata.16.1.23-36

Spradley, J. P. (1980). Participant Observation. Holt, Rinehart and Winston.

Stemler, S. E. (2015). Content Analysis. In Robert Scott and Stephen Kosslyn (Ed.), Encyclopedia of Social Measurement (pp. 1-14). John Wiley \& Sons, Inc. https://doi.org/10.1016/B0-12369398-5/00030-X

Sukriyah, S., Sumarlam, S., \& Djatmika, D. (2018). Kohesi Leksikal Sinonimi, Antonimi, Dan Repetisi Pada Rubrik Cerita Anak, Cerita Remaja, Dan Cerita Dewasa Dalam Surat Kabar Harian 
Kompas. Aksara, 30(2), 267. https://doi.org/10.29255/aksara.v30i2.230.267-283

Tamtomo, K. (2018). The Compartmentalization of Languages and Identities among Nationalist Youth in Semarang. Wacana, Vol. V(No 1), 168-190. https://doi.org/10.17510/wacana.v19i1.623.Kristian

Volkova, V. (2012). A Systemic Functional Approach to Applied Linguistic Article Conclusions. Carleton University.

Wengrum, T. D. (2015). ANALISIS KUALITAS TEKS BACAAN BUKU BAHASA INGGRIS PENERBIT ERLANGGA DAN YUDHISTIRA GHALIA SEKOLAH MENENGAH PERTAMA (SMP) KELAS VII. Sebelas Maret University.

Wiratno, T. (2018). Pengantar Ringkas Linguistik Sistemik Fungsional (1st ed.). Pustaka Pelajar.

Yuliana, D., \& Imperiani, E. D. A. (2017). The Realization of Interpersonal Meaning in Course Newsletters: A Systemic Functional Linguistic Perspective. Indonesian Journal of Applied Linguistics, 7(1), 181-188. https://doi.org/10.17509/ijal.v7i1.6873

Yusa, N., Kim, J., Koizumi, M., Sugiura, M., \& Kawashima, R. (2017). Social Interaction Affects Neural Outcomes of Sign Language Learning as A Foreign Language in Adults. Frontiers in Human Neuroscience, 11(March). https://doi.org/10.3389/fnhum.2017.00115

Zahoor, M., \& Janjua, F. (2016). Character Construction in Tributive Songs: Transitivity Analysis of the song “I am Malala." Trames, 20(2), 201-213. https://doi.org/10.3176/tr.2016.2.05 
LiNGUA Vol. 15, No. 1, June 2020 • ISSN 1693-4725 • e-ISSN 2442-3823 